The impact of HRM, perceived employability and job insecurity on self-initiated expatriates' adjustment to the host country

\begin{tabular}{|r|l|}
\hline Journal: & Thunderbird International Business Review \\
\hline Manuscript ID & TIBR-16-178.R1 \\
\hline Wiley - Manuscript type: & Research Article \\
\hline Keywords: & $\begin{array}{l}\text { Human Resource Management, Perceived Employability, Perceived Job } \\
\text { Insecurity, Self Initiated Expatriates, Adjustment }\end{array}$ \\
\hline \multicolumn{2}{|c}{} \\
\hline
\end{tabular}

SCHOLARONE ${ }^{\text {m }}$

Manuscripts 


\section{The impact of HRM, perceived employability and job insecurity on self-initiated expatriates' adjustment to the host country}

\section{Executive Summary}

Career-oriented human resource management (HRM) practices are likely to facilitate self-initiated expatriates' adjustment to the host-country. This may happen because these practices could boost one's professional development and lead to different types of career security (job security and employment security), which were probably missing in their home country and may be important elements to adjust to the host-country. Quantitative survey data from 234 Portuguese self-initiated expatriates in the United Kingdom were analyzed via structural equation modelling. Results demonstrate that career-oriented HRM practices are positively related to adjustment to the host country. These practices are also positively related to perceived job security and perceived internal employability, an indicator of employment security, but these latter variables were not significantly related to adjustment to the hostcountry. These results suggest that career-oriented HRM practices are indeed relevant for the adjustment of self-initiated expatriates, but not necessarily because they increase career security. Further analyses positively correlated adjustment to time intended to remain in the host-country.

\section{Keywords:}

Human resource management; perceived employability; perceived job insecurity; self-initiated expatriates; adjustment 


\section{INTRODUCTION}

Geographic mobility is becoming an increasingly prevalent feature of contemporary careers. Many individuals move due to international assignments arranged by the organizations they work for, whereas a large number of others move on their own initiative (Jokinen, Brewster \& Suutari, 2008). In this study, we focus on self-initiated expatriates (SIEs), individuals who themselves make the decision to live and work abroad (Peltokorpi \& Froese, 2009; Selmer \& Lauring, 2010; Tharenou \& Caulfield, 2010). The key distinction between SIEs and organizational or assigned expatriates is the initiative for the move (Cerdin \& Selmer, 2014). We focus on the particular case of Portuguese self-initiated expatriates in the UK, whose move was an individual choice but is likely to have been influenced by the recent economic crisis. The willingness to have an international experience, new experiences, professional development, career progress and economic benefits (Suutari and Brewster, 2000) would be important drivers of geographical mobility, together with the search for better job opportunities, given that many self-initiated expatriates may experience a lack of job and employment security in their home country (Cerdin \& Pargneux, 2010).

Adjustment to the host country is particularly relevant as it is positively associated with favorable attitudes and performance (Hechanova, Beehr \& Christiansen, 2003), which are important outcomes for both individuals and organizations. We aim to understand how careeroriented HRM practices implemented by organizations where SIEs work can lead to a better adjustment to the host country. We intend to do this by investigating job (in)security and employability as factors that may drive the process towards adjustment. These factors may be particularly relevant for SIEs as it seems reasonable to assume that they may be seeking job and employment security. 
One of the main predictors of expatriate adjustment relates to the multiple forms of support provided by the organization to employees and their families (see Takeuchi, 2010, for a review). In the case of assigned expatriates, their moves are initiated and supported by the organization, often using specific HRM practices tailored to expatriate management. In contrast, SIEs take the initiative in moving to a different country and getting work in an organization in the host country, meaning that it is unlikely that they receive any specific organizational support focused on the expatriation process (Jokinen et al., 2008). Nevertheless, the existence of a bundle of career-oriented HRM practices in their current organization is likely to provide them with a financial, career and social setting that facilitates adjustment to the host country. Following this rationale, the relationship between career-oriented HRM practices and adjustment to the host country can be mediated by reduced perceived job insecurity and an increase in perceived employability focusing on better job opportunities within the organization (internal) and beyond (external).

This study contributes to existing literature in two ways:

1) There is a wide array of literature on the management of organizational expatriates and on how specific practices can facilitate their adjustment to the host country (e.g. Black, Mendenhall \& Oddou, 1991; Shaffer, Harrison \& Gilley, 1999). However, self-initiated expatriates take up employment on local terms meaning that they tend to not receive the same type of objective inducements by the organization (Suutari \& Brewster, 2000). While organizational support has been linked to self-initiated expatriates' adjustment in previous qualitative research (Froese, 2012), Howe-Walsh and Schyns (2010) advanced the importance of assessing the specific role of HRM practices. For this reason, we contribute to this body of literature by quantitatively investigating the role of specific career-oriented HRM practices (rewards, career progression and training) in self- 
initiated expatriates' adjustment, which is particularly relevant as both variables may have important implications for SIEs' attitudes and behaviors in organizations.

2) Given that perceived job insecurity and lack of perceived employability are relevant drivers of searching for a job in a different country, it is pertinent to consider the role of these variables during the self-initiated expatriation process. Job security and perceived employability have been addressed before as relevant for self-initiated expatriates' careers (Cerdin \& Pargneux, 2010; Makkonen, 2015), particularly when compared with assigned expatriates (Suutari \& Brewster, 2000). However, we are among the first to explore the role of HRM as an antecedent of perceived job insecurity and perceived employability for self-initiated expatriates and their role in facilitating adjustment. By investigating these variables, we are contributing to explain the role of different types of career security in adjustment during self-initiated expatriation.

The following sections will describe the theoretical rationale behind our hypotheses. We will then present the methods used and results obtained, and afterwards we will discuss them and elaborate on their implications for research and practice.

\section{HRM and adjustment to the host country}

Expatriate adjustment has been defined as the extent to which expatriates are well integrated in daily life and work in the host location (Ward \& Kennedy, 1996), thus incorporating a work and a non-work dimension (Haslberger, Brewster \& Hippler, 2013). Cross-cultural adjustment or adaptation is a complex process in which a person becomes capable of functioning effectively in a culture other than the one he or she was originally socialized in. As people become immersed in foreign cultures their whole being gets affected (Haslberger, 2005). A meta-analysis developed by Hechanova et al. (2003) emphasizes the role of expatriate adjustment as a predictor of lower job strain, higher job satisfaction, more 
organizational commitment, fewer turnover intentions and a better job performance. For these reasons, and given that diversity is a defining feature of today's workplaces and labor market, it is in the organization's best interest that expatriates are well adjusted to life in the host country.

Self-initiated expatriates are unlikely to receive special expatriate management support from their employer, which is something commonly provided to assigned expatriates. However, the way they are managed by their employer in the host country is still likely to contribute to their adjustment to the host country. Previous research on the predictors of the adjustment of assigned expatriates advanced the relevant role of perceived organizational support (general, logistic and social support - see Takeuchi, 2010, for a review). Considering the antecedents of the adjustment of SIEs specifically, Froese's (2012) qualitative study with academic self-initiated expatriates also suggested that organizational support can be an important antecedent. While investigating perceived organizational support is extremely relevant, this construct provides a more generic depiction of an individual's perception of support. This study is particularly concerned with providing specific recommendations for HR managers, thus we wanted to investigate the role of specific HRM practices, which often promote organizational support (Tremblay et al., 2010). Howe-Walsh and Schyns (2010) suggest that HRM practices can lead to a more successful overall adjustment of self-initiated expatriates, but provide no empirical evidence. For this reason, we aim to extend previous literature by focusing on the potential favorable outcomes of career-oriented HRM practices, which may be particularly relevant for SIEs, not only for their strategic value and their impact on employee attitudes and behavior, but also because self-initiated expatriation would have been motivated by a need for career development.

For the above mentioned reasons, we now focus on the strategic HRM literature and will specifically investigate how career-oriented HRM practices in their current organization in 
the host country can be positively associated with self-initiated expatriates' adjustment to the host country. In this study we will focus specifically on three HRM practices which are likely to have a strong relevance for individuals' careers: training, career development and rewards. We chose to focus on these practices due to their strategic value, being potential antecedents of employees' attitudes and behavior (Wright \& Gardner, 2003). First, providing training would enhance employees' skills which would improve their value inside (and outside) the organization. Career development initiatives include having a well-defined performance appraisal system where the individual may foresee promotion or career enhancement opportunities. Rewards are also important factors for an individual's career and may be perceived as 'objective' indicators of one's human capital inside (and outside) the organization, and have been advanced as crucial for SIEs attraction and retention (Kim et al., 2016). This bundle of career-oriented HRM practices is likely to be positively related to self-initiated expatriates' adjustment.

All of these HRM practices provide a setting for interaction with others and strengthen one's career in the host country, which may lead to an increased financial and social status, and thus may facilitate adjustment to the host country. For these reasons, we anticipate:

H1. Career-oriented HRM practices are positively related to SIEs' adjustment to the host country.

\section{HRM, perceived job insecurity and adjustment to the host country}

Perceived job insecurity is defined as the perceived threat of losing the current job (De Witte, 2005). It is a subjective experience, since it concerns the individual's perception and interpretation of the work environment. This means that perceived job insecurity levels may vary for individuals who are in the same objective situation (Klandermans \& Van Vuuren, 
1999). Job insecurity is likely to be an important variable for SIEs, particularly for a large number of Portuguese SIEs, who have recently witnessed a situation of crisis leading to more perceived insecurity in their home country (Justino, 2016). This need for security would be combined with the desire to have an international experience and progress in their career (Suutari \& Brewster, 2000). For this reason, if self-initiated expatriates perceive that their organization is investing in them through a bundle of favorable career-oriented HRM practices, they are likely to perceive their jobs as more secure. Furthermore, organizations are more likely to invest in employees who they expect will stay with them for longer (Lepak \& Snell, 1999). This suggests that if employees perceive investment in career-oriented HRM practices, they are likely to perceive more job security. A robust set of career-oriented HRM practices is thus likely to be negatively related to perceived job insecurity:

H2a). Career-oriented HRM practices are negatively related to SIEs' perceived job insecurity.

Job insecurity is likely to be a relevant variable for self-initiated expatriates as it may be something that they desire and that motivated them to move to a different country in the first place (Froese, 2012; Suutari \& Brewster, 2000), together with other individual motives. Perceived job insecurity is also negatively related to employee well-being (De Cuyper \& De Witte, 2006), and SIEs' adjustment to the host country may be an important factor for their well-being (Lee, 2005). SIEs who are more secure about their jobs have greater career and financial security, which allows them to make longer-term plans in the host-country (e.g. purchasing a house and establishing stronger social ties). The longer-term connotation of job security in the host country is likely to make SIEs consolidate their social interactions and cope better with general aspects of adjustment to the host country. Thus, we hypothesize:

H2b). Perceived job insecurity is negatively related to SIEs' adjustment to the host country. 
For the above mentioned dimensions, perceived job insecurity is likely to explain the relationship between career-oriented HRM practices and self-initiated expatriates' adjustment to the host country:

H2c). Perceived job insecurity negatively mediates the positive relationship between career-oriented HRM practices and SIEs' adjustment to the host country.

\section{HRM, perceived employability and adjustment to the host country}

Job insecurity is often associated with the construct of perceived employability (PE). These are related but different constructs: while perceived job insecurity concerns the present job in the present organization, perceived employability concerns potential future jobs in the labor market. Perceived employability (PE) refers to an individual's beliefs about how easy it is to find new employment (Rothwell \& Arnold, 2007), or their perception about possibilities of finding a new job (Berntson, Sverke \& Marklund, 2006). Perceived employability is a twofold concept: internal and external (Berntson et al., 2006) - with the current employer or on the external labor market. This distinction between perceived internal and external employability has been widely discussed and empirically demonstrated (e.g. Van der Heijden, 2002; Forrier \& Sels, 2003; Rothwell \& Arnold, 2007; De Cuyper \& De Witte, 2008, 2011; Van den Broeck et al., 2014). Internal and external perceived employability are categories that can be further divided into lateral or upward. Lateral perceived employability refers to the possibilities of finding a similar job, while upward perceived employability refers to the possibilities of finding a better job (Van den Broeck et al., 2014). Given that some of the main motives of selfinitiated expatriates for moving to a different country are to improve their employment situation, develop themselves professionally and progress in their careers (Suutari \& Brewster, 2000), we decided to focus our attention on internal and external upward PE. 
According to longitudinal empirical data from Wittekind, Raeder \& Grote (2009), education, support for career and skill development, current level of job-related skills, and willingness to change jobs are significant predictors of perceived employability. This evidence is aligned with the idea that beyond 'personal' factors (agency), there is a strong relevance of contextual factors (structure) in influencing perceived employability (see Forrier, Sels \& Stynen, 2009, for a review on the agency vs. structure debate). In this study we will focus specifically on support for career and skill development, which in practice translates into career-oriented HRM practices that the self-initiated expatriates may or may not be receiving from their employer.

The above mentioned practices are then likely to increase employees' internal upward PE, but also external upward PE, through the development of both firm-specific and transferrable human capital, respectively. We anticipate that career-oriented HRM practices implemented by employers will have a positive role in enhancing both internal and external PE. Although enhancing external PE may not exactly be desired by organizations (see literature on the management paradox - De Cuyper \& De Witte, 2011; Nelissen, Forrier \& Verbruggen, 2017; Van der Heijde \& Van der Heijden, 2006), it is likely that this effect is going to occur anyway, due to the enhancement of individuals' human capital (both firmspecific and transferrable). Accordingly, we hypothesize:

H3a). Career-oriented HRM practices are positively related to SIEs' external upward $P E$.

H4a). Career-oriented HRM practices are positively related to SIEs' internal upward $P E$.

A high level of internal upward PE suggests that individuals may see a favorable career path in the organization, which may be correlated to a favorable financial and social status. The same is true for external upward PE, even though it is not about their career in the same 
organization. Given that the major motivations of self-initiated expatriates relate to professional development, career progress, economic benefits and improving their employment situation (Suutari \& Brewster, 2000), a belief that they can achieve those (by having high levels of internal and external upward PE) is likely to be positively related to their levels of adjustment to the host country. Additionally, internal and external upward PE have a long-term connotation, which is likely to make self-initiated expatriates consolidate their social interactions and cope better with general aspects of adjustment to the host country (Black et al., 1991). For these reasons we hypothesize:

H3b). External upward PE is positively related to SIEs' adjustment to the host country. H3c). External upward PE mediates the positive relationship between career-oriented HRM practices and SIEs' adjustment to the host country.

H4b). Internal upward PE is positively related to SIEs' adjustment to the host country. H4c). Internal upward PE mediates the positive relationship between career-oriented HRM practices and SIEs' adjustment to the host country.

Figure 1 presents a model, which combines the different hypotheses being tested in this study.

Insert Figure 1 about here

\section{METHODS}

\section{Context}

While there are individual drivers of self-initiated expatriation, such as the desire to have new international work experiences, career development and an increase in economic gains (Suutari \& Brewster, 2000), we believe that the context may have played an important role among Portuguese SIEs. The number of nationals from European Union (EU) countries moving to the United Kingdom (UK) rose from 65,000 in the year ending September 2012, to 184,000 in the year ending March 2015 (Hawkins, 2016), which is partly associated with the 
fact that EU citizens have freedom of movement to work in other member countries. In 2014, $3.2 \%$ of foreign nationals in the UK were Portuguese (Rienzo \& Vargas-Silva, 2016). The number of Portuguese nationals moving to the UK has increased from 1,800 in 2000 to 30,120 in 2013, doubling between 2011 and 2013 (Pires et al., 2014). The large increase in the number of Portuguese self-initiated expatriates, especially after the year 2010, is related to the effects of the economic crisis and the growth in unemployment rates in Portugal. The absence of opportunities and elimination of jobs led individuals to move to countries where more opportunities may be available (Justino, 2016).

\section{Data collection and respondents}

Data were collected between September and November 2014 by means of online questionnaires. Questionnaires were published and shared in social media, and the number of responses by IP address was automatically restricted to one. In particular, questionnaires were shared on the two largest generic Facebook and LinkedIn groups of Portuguese individuals working in the UK. This choice of social media groupings, which included numerous professions was meant to retrieve a heterogeneous sample that would be as representative as possible of the Portuguese SIEs currently working in the UK. Confidentiality and anonymity were guaranteed to participants. Participants were 241 Portuguese individuals currently working in the United Kingdom across different sectors to maximize the possibility of generalizing findings. After list wise deletion of cases with more than 10 missing values, we had a total sample size of 234 respondents.

As regards demographics, more women (59\%) than men participated (41\%). The distribution of respondents according to education was heterogeneous: $20.5 \%$ had studied up to the mandatory $9^{\text {th }}$ grade of the Portuguese education system, $32.5 \%$ had attended and/or finished secondary school, 34.2\% held a Bachelor's Degree, $11.6 \%$ held a Master's Degree and three people $(1.5 \%)$ held a Doctorate. Mean age was 34 years $(\mathrm{SD}=9.08)$. The median time 
living in the United Kingdom was 2 years and five months. Regarding contract type, $55.1 \%$ had permanent contacts, $22.1 \%$ had fixed-term contacts, $7.3 \%$ had contracts of unspecified duration, $5.6 \%$ were temporary agency workers, $6.4 \%$ were self-employed, and $5.6 \%$ were on zero-hour contracts. For our analyses, we created a dummy variable where we merged permanent workers and self-employed individuals into one category (permanent) which accounted for $61.5 \%$ of the sample and the remaining groups into another category (temporary). $38 \%$ of respondents had signed a contract with their employer before moving to the United Kingdom.

Self-initiated expatriates or migrants? Al Ariss (2010) reviewed literature comparing the definitions 'self-initiated expatriates' and 'migrant' workers. The key aspects that would distinguish them would be: the country of origin; volition; status in the host society and permanence in the host country. Classifying a worker as a self-initiated expatriate or a migrant worker may not be easy as there may be multiple combinations regarding country of origin, volition, permanence and status in the host society. Participants in our sample were moving between two European developed countries, their decision to move is mostly voluntary, and their status in the host country is relatively good (the majority attended higher education and have permanent contracts in the UK). Nevertheless, central to the distinction is permanency participants in our sample would be classified as self-initiated expatriates if they intend to stay for a limited period of time. In fact, $49.6 \%$ of the respondents want to go back to Portugal as soon as possible, $13.2 \%$ want to go back to Portugal but do not mind staying a few more years abroad, $16.7 \%$ do not want to go back and $19.2 \%$ say they are unsure). We decided not to remove the $16.7 \%$ of workers who said that they do not want to go back from the sample. This has to do with the fact that we also asked our respondents to let us know (in open-ended answers) for how long they would like to live in the UK and for how long they would like to live outside Portugal, but not in the UK. Nineteen percent of respondents who said that they 
would not like to return to Portugal also indicated that they plan to move to different places other than the UK. Furthermore, the potential future environmental changes in the host country (in particular the June 2016 'Brexit' referendum result and the UK leaving the European Union) may alter the status of SIEs and change their perception about remaining. For these reasons, we believe we cannot necessarily exclude them from the category of self-initiated expatriates in that host country. Furthermore, similarly to those who now wish to go back to Portugal and may eventually change their opinion becoming immigrants, those who now say they do not wish to return may also change their opinion.

The characterization of our participants as self-initiated expatriates is also aligned with the more recent conceptualization by Cerdin and Selmer (2014), as their process of relocation was self-initiated, they were in regular employment, most of them had intentions of a temporary stay and had jobs aligned with their skill set.

\section{Measures}

Adjustment to the host country. In order to measure respondents' adjustment to life in the United Kingdom we used 9 interaction and general adaptation items from Black and Stephens' (1989) scale. Work adaptation items were not included in this study. We chose this option during the development of the questionnaire as we were particularly interested in how work-related aspects such as career-oriented HRM practices would relate to non-work-related adjustment, specifically general and interaction adjustment. This approach is the same used by Robie and Ryan (1996) and Haslberger (2005) who also excluded work adaptation items from the Black and Stephens' scale. The item regarding adjustment to shopping was removed from our analyses due to a very high number of missing values for this item. Respondents were asked to indicate how unadjusted (1) or adjusted (7) they were regarding: living conditions in general, food, housing conditions, health care facilities, entertainment/recreation facilities and 
opportunities, cost of living, socializing with host nationals, and interacting with host nationals on a day-to-day basis. We considered interaction and general adaptation items as a single factor, since we ran an exploratory factor analysis in principal components explaining $52.94 \%$ of the variance which supported the extraction of one single component $(\alpha=.87)$.

Human Resource Management Practices. To assess how favorable were employees' perceptions of the human resource management practices that are being implemented in the organizations where they are currently working, we used nine items from a previously validated scale in the Portuguese context (Dias, 2013). We selected three main HRM practices, which were likely to have the strongest impact on employees' career: training, career development and rewards. We performed a confirmatory factor analysis with three factors representing each of the three practices, which will be described in the Results section. Sample items for the three HRM practices were: training - 'When I think of the training that I received in this organization, it has been adequate to develop my professional skills' $(\alpha=.96)$; career development 'When I think of my career development in this organization, the organization promotes adequate support to develop my career' $(\alpha=.87)$; and rewards - 'When I think of the rewards I received in this organization, I believe they are adequately related to my performance results’ $(\alpha=.93)$.

Perceived Internal and External Upward Employability. Upward PE was measured with eight items from De Cuyper and De Witte (2008; 2010). Respondents were asked to rate their level of agreement with each statement on a five-point Likert scale $(1=$ strongly disagree to $5=$ strongly agree). Internal upward PE referred to the perception of better employment opportunities in the current organization. A sample item was 'I can easily find a better job in this organization, instead of my present job'. The Cronbach alpha for the four items measuring internal upward PE was .87. The remaining four items represented external upward PE, which refers to the perception of better employment opportunities outside the current organization 
(i.e., with different employers). A sample item was 'I can easily find a better job with another employer, instead of my present job'. Reliability (Cronbach's alpha) was .81 .

Perceived Job Insecurity. Perceived job insecurity was measured with the 4-item Job Insecurity Scale of De Witte (2000). This scale was further validated by Vander Elst, De Witte, and De Cuyper (2014). Items were rated on a 5-point Likert-type scale ranging from 1 (totally disagree) to 5 (totally agree). A sample item is 'I think I will lose my job in the near future'. Cronbach's alpha for this scale was .89.

Control Variables. Age, gender, education, time spent in the host country and contract type were included in our analyses as control variables. Age and gender were introduced as control variables in the model as previous research suggested they could influence SIEs' adjustment to the host country (Isakovic \& Whitman, 2013; Koveshnikov, Wechtler \& Dejoux, 2014), meaning that this can also be a relevant variable to self-initiated expatriates. We also decided to control for education as it may have a positive relationship with PE (Berntson et al., 2006) and ultimately adjustment. We additionally controlled for contract type, which is likely to be related to work quality (and permanence) and play an important role in perceived job insecurity and PE (De Cuyper, Notelaers \& De Witte, 2009) and ultimately may impact adjustment to the host country. Time spent in the host country was also controlled for in our analyses due to its possible relationship with adjustment as demonstrated in previous research (e.g. Bhaskar-Shrinivas et al., 2005; Hippler, Brewster \& Haslberger, 2015).

\author{
Analyses \\ Hypotheses were tested with Structural Equation Modelling (SEM) using the AMOS \\ 22.0 software package. No violations regarding multi-collinearity or non-normality were found \\ (Weston \& Gore, 2006). Therefore, the maximum likelihood method was selected as the \\ estimation procedure.
}


We followed a two-step procedure, in line with recommendations made by Anderson and Gerbing (1988). In a first step, we used Confirmatory Factor Analysis (CFA) to evaluate the construct validity of the study's scales, inspecting risks associated with common method variance, and achieving an acceptable measurement model. The hypothesized measurement model was tested and compared with two alternative models. The hypothesized model included five latent factors representing career-oriented HRM practices, perceived job insecurity, external upward PE, internal upward PE and adjustment to the host country. Training, career development and rewards were represented as single scale score indicators loading on one factor (career-oriented HRM practices). The option of representing these variables as single scale score indicators was chosen because doing otherwise would substantially increase the number of parameters in the model, which would not be consistent with the recommended sample size-to-parameter ratio of 5 to 1 (Bollen, 1989). In the case of relatively small samples like ours, it is an option to create composite or aggregate variables where all the items are averaged into a single variable (Landis, Beal, \& Tesluk, 2000). We conducted a separate confirmatory factor analysis to test for convergent and divergent validity of the career-oriented HRM practices scale, before transforming the sub-factors into single score indicators. The model also included age, gender, education, time in the host country and contract type, our control variables, as single item indicators (MModelH).

We compared the hypothesized model with a one-factor model in which all items were loaded on the same latent factor (MModel1). We have also compared the hypothesized model with an alternative two-factor model, where HRM items and adjustment items loaded on one factor and items related to perceived job insecurity and both forms of perceived employability loaded on another factor. In this model, control variables were presented separately as single scale score indicators (MModel2). In all models, the variables were allowed to correlate, except for indicators loading on a factor. 
In the second step, we tested our hypothesized structural model (Figure 1).

Model fit was evaluated based on the Tucker-Lewis Index (TLI), the Bentler Comparative Fit Index (CFI), and the Root Mean Square Error of Approximation (RMSEA) and the Standardized Root Mean Square Residual (SRMR). Values of .0.90, or, more conservatively, .0.94 for TLI and CFI, and values of, 0.08 or, more conservatively, 0.06 , for RMSEA and SRMR are representative for a well-fitting model (Hu \& Bentler, 1999). Model comparisons were based on Chi-square difference tests.

\section{RESULTS}

\section{Descriptive statistics}

The means, the standard deviations, and the correlations for all scales are shown in Table 1. Training, career development opportunities and rewards were positively correlated with internal upward PE. Internal and external upward PE were positively correlated. Perceived job insecurity was negatively correlated with training and career development opportunities. There were no significant correlations between age, gender, education, time living in the host country and contract type with our studied variables, except for career development opportunities, which were negatively correlated with age, and for rewards, which were more satisfactory for males.

Insert Table 1 about here

\section{Measurement Models}

Before testing our measurement models, we conducted confirmatory factor analysis of the career-oriented HRM scale. The model had three factors representing each of the three practices and presented a good fit: $\chi_{(24)}^{2}=50.67, \mathrm{p}<.01, T L I=.98, C F I=.99$, RMSEA $=.07$, $S R M R=.04$. We have also tested for alternative factorial arrangements: a model where all 
items loaded on one factor $\left(\chi_{(27)}^{2}=831.07, \mathrm{p}<.001, T L I=.47, C F I=.61, R M S E A=.36\right.$, SRMR $=.20$ ) and a model where items from career development and training loaded on a single factor and items from rewards loaded on another factor $\left(\chi_{(26)}^{2}=308.88, \mathrm{p}<.001, T L I=.81, C F I=.86\right.$, $R M S E A=.22, S R M R=.15)$. The three factor model had a significantly better fit to our data compared to the one-factor model $\left(\Delta \chi_{(3)}^{2}=780.4, \mathrm{p}<.001\right)$ and to the two-factor model $\left(\Delta \chi^{2}{ }_{(2)}\right.$ $=258.21, \mathrm{p}<.001)$. We then transformed these three factors into single-item indicators: rewards, career progression and training.

The hypothesized measurement model $(\mathrm{MModelH})$ provided an acceptable fit $\left(\chi_{(308)}^{2}=\right.$ $517.01, \mathrm{p}<.001, \mathrm{TLI}=.91, \mathrm{CFI}=.92, \mathrm{RMSEA}=.05, \mathrm{SRMR}=.06)$. The initial fit of the model was: $\chi_{(310)}^{2}=575.38, \mathrm{p}<.001, \mathrm{TLI}=.88, \mathrm{CFI}=.90, \mathrm{RMSEA}=.06, \mathrm{SRMR}=.06$. After inspecting the modification indices, we allowed two items within external upward PE to correlate, as well as two items within the adjustment factor. The alternative one-factor measurement model (MModel1) provided a poor fit to our data $\left(\chi_{(348)}^{2}=2190.29, \mathrm{p}<.001\right.$, TLI $=.27, \mathrm{CFI}=.33, \mathrm{RMSEA}=.15, \mathrm{SRMR}=.15)$. The other alternative model, MModel2, also provided a poor fit $\left(\chi_{(332)}^{2}=1588.38, \mathrm{p}<.001, \mathrm{TLI}=.48, \mathrm{CFI}=.54, \mathrm{RMSEA}=.13, \mathrm{SRMR}=\right.$ .14). Our hypothesized measurement model (MModelH) was compared to the remaining models by means of the chi-square difference test and provided a significantly better fit (MModelH vs. MModel1 $-\Delta \chi_{(40)}^{2}=1673.29, \mathrm{p}<.001 ;$ MModelH vs MModel2 $-\Delta \chi_{(24)}^{2}=$ 1071.37, $\mathrm{p}<.001)$

\section{Structural Model}

In order to test our hypotheses, we ran the structural model represented in Figure 2. The hypothesized structural model yielded an acceptable fit to the data: $\chi_{(308)}^{2}=517.01, p<.001$, $T L I=.91, C F I=.92, R M S E A=.05, S R M R=.06)$. Hypothesis 1 was supported as career- 
oriented HRM practices were positively and significantly related to adjustment to the host country $(\beta=.42 ; \mathrm{p}<.001)$. Hypothesis $2 \mathrm{a})$ was supported as we found a negative relationship between career-oriented HRM practices and perceived job insecurity $(\beta=-.21 ; p<.01)$. However, the relationship between perceived job insecurity and adjustment to the host country was not significant $(\beta=-.07 ; \mathrm{p}=.32)$, meaning that $\mathrm{H} 2 \mathrm{~b})$ and $\mathrm{H} 2 \mathrm{c}$ ) were not supported. Hypotheses 3a), 3b) and 3c) were not supported as the relationship between career-oriented HRM and external upward PE $(\beta=.08 ; p=.32)$, and the relationship between external upward $\mathrm{PE}$ and adjustment to the host country $(\beta=.06 ; \mathrm{p}=.44)$ were not significant, which also rejects the possibility of a mediation. Hypothesis 4a) was supported since we found a significant positive relationship between career-oriented HRM and internal upward $\operatorname{PE~}(\beta=.61 ; \mathrm{p}<.001)$. Hypotheses $4 b$ ) and 4c) were not supported as the relationship between internal upward PE and adjustment to the host country was not significant $(\beta=-.12 ; p=.26)$. Table 2 presents the regression weights of the control variables added to the model (age, gender, education, time in the host country and contract type) on mediating and dependent variables. None of these variables were significantly related to perceived job insecurity, external upward PE, internal upward PE, nor to adjustment to the host country.

Insert Figure 2 about here

Insert Table 2 about here

Given the non-significant relationships between our mediators and adjustment to the host country, we decided to conduct further analyses in order to explore the reasons for these findings. We considered an additional variable represented by the question: "For how long would you like to stay in the UK?". Responses were coded as: $1=$ Less than 3 years; $2=$ From 
3 to 5 years; $3=$ from 6 to 10 years; $4=$ from 11 to 15 years; $5=$ from 16 to 25 years; $6=$ more than 25 years. Correlation analyses demonstrated that an intention to stay in the UK for longer was significantly and positively related to higher levels of adjustment $(r=.15 ; p<.05)$. A longer intended permanence in the host country was also related to and older age ( $r=.27 ; p<.001)$, to having children $(\mathrm{r}=.22 ; \mathrm{p}<.01)$, to a lower educational level $(\mathrm{r}=-.17 ; \mathrm{p}<.01)$, to a longer time spent in the UK $(\mathrm{r}=.19 ; \mathrm{p}<.01)$, to a more favorable perception of rewards received $(\mathrm{r}=.15$; $\mathrm{p}<.05)$ and to a higher internal upward $\operatorname{PE~}(\mathrm{r}=.18 ; \mathrm{p}<.01)$.

\section{DISCUSSION}

This study provided insightful new results about (1) the positive relationship between career-oriented HRM practices and adjustment to the host country; (2) the relationships between career-oriented HRM practices and perceived job insecurity, as well as internal and external upward PE; and (3) the non-significant relationships between perceived job insecurity, internal and external upward PE, and adjustment to the host country among a group of Portuguese SIEs currently living and working in the UK. These results are now discussed in detail.

First, our results supported H1, which stated that career-oriented HRM practices, in particular referring to training, career progression systems and rewards, were positively related to adjustment to the host country. These results are consistent with previous research on assigned expatriates (Takeuchi, 2010), who receive a much stronger formal support by their organizations. These results also further quantitatively test previously published propositions and qualitative data on self-initiated expatriates (Froese, 2012; Howe-Walsh \& Schyns, 2010). In particular, we provide innovative evidence suggesting that career-oriented HRM practices provide a favorable setting that helps self-initiated expatriates learn how to deal with the 
practicalities of living in the host country and also possibly establish networks that help them become more socially adjusted.

Second, we anticipated that career-oriented HRM practices were negatively related to perceived job insecurity (H2a). Our results supported this hypothesis, which suggests that the set of inducements that organizations provide to employees is indeed going to make them feel more secure about the future of their jobs. This is particularly relevant since we are focusing on a sample of self-initiated expatriates who are likely to have experienced high levels of perceived job insecurity in their home country, Portugal, especially in the past six years (Justino, 2016). We have now contributed to research by empirically finding that if selfinitiated expatriates receive career-oriented HRM practices from their employers, this relates to lower levels of perceived job insecurity. Organizational investment in reducing job insecurity is likely to be beneficial for employees' attitudes and behavior in the workplace, as well as their occupational health (Cheng \& Chan, 2008).

Third, we anticipated that career-oriented HRM practices were positively related to internal upward PE (H4a). Our results supported this assumption, which indicates that the type of career-oriented HRM practices being implemented by the employers in our sample were mostly effective in enhancing the employees' perceptions that there are indeed possibilities of obtaining a better job in the organization. We additionally anticipated that career-oriented HRM practices would also be positively related to external upward PE (H3a), as employees would be gaining more transferable skills and increasing their marketability (Mäkelä et al., 2015). We found that this relationship was not significant, which suggests that most of the career-oriented HRM practices implemented by organizations are specifically designed to enhance organization-specific skills, rather than transferable skills. There is also a low correlation between internal and external upward PE. This is consistent with the idea that perceptions of job opportunities in the internal or external labor market are at least partly based 
on a different combination of individual and organizational factors (Rothwell \& Arnold, 2007;

Forrier et al., 2009). Internal perceived employability would be mostly regarded as a responsibility that is shared by employees and employers, while external perceived employability would be mostly the employees' responsibility (De Cuyper \& De Witte, 2011). It may also reflect understanding of the external labor market. Thus, our results support the notion that employers are unlikely to invest in general transferable skills because a return on such investments is less likely when employees' profiles are in demand (Van den Broek et al., 2014). This evidence suggests that the management paradox claiming that investing in human resources may lead to an increase external PE and potentially to employee turnover (De Cuyper \& De Witte, 2011; Nelissen et al., 2017) may not actually be a strong issue, for organizations seem, in general, to be more focused on developing organization-specific skills rather than transferable ones.

We additionally anticipated that perceived job insecurity was negatively (H2b), and external upward PE (H3b) and internal upward PE (H4b) were positively related to selfinitiated expatriates' adjustment to the host country. We also hypothesized that perceived job insecurity, external upward PE and internal upward PE were mediators in the positive relationship between career-oriented HRM practices and adjustment to the host country $(\mathrm{H} 2 \mathrm{c}$, $\mathrm{H} 3 \mathrm{c}$ and $\mathrm{H} 4 \mathrm{c}$ ). Our results did not support these hypotheses. Although we found a strong direct relationship between career-oriented HRM practices and adjustment to the host country, the links between our expected mediators and the outcome were not significant, which consequently invalidated mediation. Perceived job insecurity, internal and external upward PE can be relevant variables for self-initiated expatriates and possibly aspects that motivated them to move to the host country. Perceived job insecurity and internal upward PE are possibly elements that reduce and facilitate (respectively) the creation of a long-term employment setting in the host country, which would probably facilitate adjustment and consequent well- 
being (Lee, 2005). However, the demographic data indicated that a long-term permanence in the UK may not be what these Portuguese self-initiated expatriates are looking for. Of course, their ideas may change. Al Ariss and Ozbilgin (2010, p. 276) noted that "many self-initiated expatriates stay on a permanent basis and thus become permanent immigrants”. Eventually, this group of self-initiated expatriates (or part of it) might become a group of immigrants, and our additional analyses demonstrated a strong positive correlation between a longer intended permanence in the UK and adjustment. However, it seems that this long-term perception may not exist for most of our participants yet: the idea of adjustment may be important for these individuals as a temporary well-being element rather than a long term one. This may be the reason why perceived job insecurity, internal and external upwards PE (which relate to career opportunities in the host country and thus long-term stability) were not significantly related to adjustment to the host country.

\section{Limitations and future research directions}

Perhaps the most important limitation of this study is its cross-sectional design, which hampers causal interpretations. However, our hypotheses aligned with theory and earlier longitudinal research, which may suggest that career-oriented HRM practices are more likely to be antecedents of perceived employability and perceived job insecurity (De Cuyper \& De Witte, 2011; Wittekind et al., 2009), as well as adjustment to the host country (Suutari \& Brewster, 2000), rather than the other way around. An important route for future research could be to test these underlying dynamics, preferably with a longitudinal design.

Another limitation concerns the risk of common method variance due to using selfreported data. According to Podsakoff, Mackenzie, Lee and Podsakoff (2003), survey data is likely to be biased due to social desirability, acquiescence and negative affectivity, which may lead to common method variance. Some authors, however, argue that the magnitude of the 
possible inflation of relationships due to common method variance should not be overestimated (e.g. Crampton \& Wagner, 1994). We have additionally followed Podsakoff et al.'s (2003) suggestions for questionnaire design that may reduce the risk of common method variance. Also, we performed a confirmatory factor analysis, which showed that our hypothesized model had the most robust factorial distribution, meaning that our variables are indeed different.

Future research should try to replicate our findings among other groups of self-initiated expatriates to investigate whether they would be consistent in different contexts (i.e., different expatriates and different host countries). It is also important to note that these results were obtained before the 'Brexit' referendum result, supporting UK's withdrawal from the European Union. It would now be particularly relevant to assess whether the perceptions of Portuguese SIEs have changed after knowing the 'Brexit' referendum result.

\section{Concluding Remarks and Practical Implications}

This study's findings have important practical implications. Our study provided innovative evidence about the role of career-oriented HRM practices, perceived employability, perceived job insecurity, and adjustment to the host country for self-initiated expatriates. Specifically, we established that although self-initiated expatriates are employed on the host country organization's own terms and conditions, if these organizations are implementing career-oriented HRM practices, these are likely to have a positive role in facilitating the adjustment of these employees. This may be relevant for organizations that are interested in retaining these self-initiated expatriates: career-oriented HRM practices will make self-initiated expatriates more adjusted to non-work related aspects, which can possibly buffer the home country's pull factors for repatriation and make them less likely to leave the organization (Tharenou \& Caulfield, 2010). Contrary to expectations, the relationship between career- 
1

2

3

4

5

6

7

8

9

10

11

12

13

14

15

16

17

18

19

20

21

22

23

24

25

26

27

28

29

30

31

32

33

34

35

36

37

38

39

40

41

42

43

44

45

46

47

48

49

50

51

52

53

54

55

56

57

58

59

60 oriented HRM practices and adjustment to the host country was not mediated by perceived job insecurity nor by internal or external upward PE. This suggests that career-oriented HRM practices are not necessarily relevant for non-work adjustment to the host country because they relate to job security or perceived employability as indicators of one's human capital, but instead because they may facilitate a context for new learnings and networking. 


\section{REFERENCES}

Al Ariss, A. (2010). Modes of engagement: migration, self-initiated expatriation, and career development. Career Development International, 15(4), 338-358.

Al Ariss, A. \& Ozbilgin, M. (2010). Understanding self-initiated expatriates: Career experiences of Lebanese self-initiated expatriates in France. Thunderbird International Business Review, 52(4), 275-285.

Anderson, J.C. \& Gerbing, D.W. (1988). Structural equation modelling in practice: a review and recommended two-step approach. Psychological Bulletin, 103(3), 411-423.

Berntson, E., Sverke, M. \& Marklund, S. (2006). Predicting perceived employability: Human capital or labour market opportunities? Economic and Industrial Democracy, 27(2), 223-244.

Bhaskar-Shrinivas, P., Harrison, D.A., Shaffer, M.A. \& Luk, D.M. (2005). Input-based and time-based models of international adjustment: meta-analytical evidence and theoretical extensions. Academy of Management Journal, 482(2), 257-281.

Black, J.S. \& Stephens, G.K. (1989). The influence of the spouse on American expatriate adjustment and intent to stay in Pacific Rim overseas assignments. Journal of Management, 15(4), 529-544.

Black, J.S., Mendenhall, M. \& Oddou, G. (1991). Toward a comprehensive model of international adjustment: An integration of multiple theoretical perspectives. Academy of Management Review, 16(2), 291-317.

Bollen, K.A. (1989). Structural equations with latent variables. New York, NY: Wiley.

Cerdin, J.-L. \& Pargneux, M.L. (2010). Career anchors: A comparison between organizationassigned and self-initiated expatriates. Thunderbird International Business Review, 52(4), 287-299. 
Cerdin, J.-L. \& Selmer, J. (2014). Who is a self-initiated expatriate? Towards conceptual clarity of a common notion. The International Journal of Human Resource Management, 25(9), 1281-1301.

Cheng, G.H.-L. \& Chan, D.K.-S. (2008). Who suffers more from job insecurity? A metaanalytic review. Applied Psychology, 57(2), 272-303.

Crampton, S.M. \& Wagner, J.A. (1994). Percept-percept inflation in micro organizational research. Journal of Applied Psychology, 79(1), 67-76.

De Cuyper, N. \& De Witte, H. (2006). The impact of job insecurity and contract type on attitudes, well-being and behavioural reports: A psychological contract perspective. Journal of Occupational and Organizational Psychology, 79(3), 395-409.

De Cuyper, N. \& De Witte, H. (2008). Gepercipieerde kans op een baan versus een betere baan: Relaties met arbeidstevredenheid en welzijn (Perceived chances on a job versus a better job: Associations with job satisfaction and well-being). Gedrag \& Organisatie, 21(4), 475-492.

De Cuyper, N. \& De Witte, H. (2010). Temporary employment and perceived employability: Mediation by impression management. Journal of Career Development, 37(3), 1-18.

De Cuyper, N. \& De Witte, H. (2011). The management paradox: Self-rated employability and organizational commitment and performance. Personnel Review, 40(2), 152-172.

De Cuyper, N., Notelaers, G. \& De Witte, H. (2009). Job insecurity and employability in fixedterm contractors, agency workers, and permanent workers: Associations with job satisfaction and affective organizational commitment. Journal of Occupational Health Psychology, 14(2), 193-205.

De Witte, H. (2000). Arbeidethos en jobonzekerheid: Meting en gevolgen voor welzijn, tevredenheid en inzet op het werk [Work ethic and job insecurity: Assessment and consequences for well-being, satisfaction and performance at work]. In R. Bouwen, K. 
De Witte, H. De Witte \& T. Taillieu (Eds.), Van groep tot gemeenschap [From group to community]. Liber Amicorum Prof. Dr. Leo Lagrou: 325-350. Leuven, Belgium: Garant.

De Witte, H. (2005). Job insecurity: Review of the international literature on definitions, prevalence, antecedents and consequences. South African Journal of Industrial Psychology, 31(4), 1-6.

Dias, A. (2013). O impacto das práticas de gestão de recursos humanos no desempenho profissional: O efeito de mediação do engagement no trabalho [The impact of human resource management practices on professional performance: The mediating effect of work engagement]. Lisbon: ISPA-IU.

Forrier, A. \& Sels, L. (2003). The concept of employability: A complex mosaic. International Journal of Human Resource Development and Management, 3(2), 103-124.

Forrier, A., Sels, L. \& Stynen, D. (2009). Career mobility at the intersection between agent and structure: A conceptual model. Journal of Occupational and Organizational Psychology, 82(4), 739-759.

Froese, F. J. (2012). Motivation and adjustment of self-initiated expatriates: The case of expatriate academics in South Korea. The International Journal of Human Resource Management, 23(6), 1095-1112.

Hawkins, O. (2016). Migration Statistics - Briefing Paper Number SN06077. London: House of Commons Library.

Haslberger, A. (2005). Facets and dimensions of cross-cultural adaptation: Refining the tools. Personnel Review, 34(1), 85-109.

Haslberger, A., Brewster, C. \& Hippler, T. (2013). The dimensions of expatriate adjustment. Human Resource Management, 52(3), 333-351. 
Hechanova, R., Beehr, T. A. \& Christiansen, N. D. (2003). Antecedents and consequences of employees' adjustment to overseas assignments: A meta-analytic review. Applied Psychology: An International Review, 52(2), 213-236.

Hippler, T., Brewster, C. \& Haslberger, A. (2015). The elephant in the room: The role of time in expatriate adjustment. International Journal of Human Resource Management, 26(15), 1920-1935.

Howe-Walsh, L. \& Schyns, B. (2010). Self-initiated expatriation: implications for HRM. The International Journal of Human Resource Management, 21(2), 260-273.

Hu, L. \& Bentler, P.M. (1999). Cut-off criteria for fit indices in covariance structure analysis: conventional criteria versus new alternatives. Structural Equation Modeling, 6(1), 1-55.

Isakovic, A. \& Whitman, M.F. (2013). Self-initiated expatriate adjustment in the United Arab Emirates: a study of academics. Journal of Global Mobility, 1(2), 161-186.

Jokinen, T., Brewster, C. \& Suutari, V. (2008). Career capital during international work experiences: contrasting self-initiated expatriate experiences and assigned expatriation. The International Journal of Human Resource Management, 19(6), 979-998.

Justino, D. (2016). Emigration from Portugal: Old wine in new bottles? Washington, DC: Migration Policy Institute.

Kim, K., Halliday, C. S., Zhao, Y., Wang, C. \& Von Glinow, M. A. (2016). Rewarding selfinitiated expatriates: A skills-based approach. Thunderbird International Business Review. doi:10.1002/tie.21832

Klandermans, B. \& van Vuuren, T. (1999). Job insecurity: Introduction. European Journal of Work and Organizational Psychology, 8(2), 145-153.

Koveshnikov, A., Wechtler, H. \& Dejoux, C. (2014). Cross-cultural adjustment of expatriates: The role of emotional intelligence and gender. Journal of World Business, 49(3): 362371. 
Landis, R.S., Beal, D.J. \& Tesluk, P.E. (2000). A comparison of approaches to forming composite measures in structural equation models. Organizational Research Methods, 3(2), 186-207.

Lee, C.H. (2005). A study of underemployment among self-initiated expatriates. Journal of World Business, 40(2), 172-187.

Lepak, D. P. \& Snell, S. A. (1999). The human resource architecture: toward a theory of human capital allocation and development. Academy of Management Review, 24(1), 25-48.

Nelissen, J., Forrier, A., \& Verbruggen, M. (2017). Employee development and voluntary turnover: Testing the employability paradox. Human Resource Management Journal, $27(1), 152-168$.

Mäkelä, L., Suutari, V., Brewster, C., Dickmann, M. \& Tornikoski, C. (2015). The impact of career capital on expatriates' perceived marketability. Thunderbird International Business Review, 58(1), 29-40.

Makkonen, P. (2015). Perceived employability development of Western self-initiated expatriates in local organisations in China. Journal of Global Mobility, 3(4), 350-377.

Peltokorpi, V. \& Froese, F.J. (2009). Organizational expatriates and self-initiated expatriates: who adjusts better to work and life in Japan? The International Journal of Human Resource Management, 20(5), 1096-1112.

Pires, R.P., Pereira, C., Azevedo, J. \& Ribeiro, A.C. (2014). Emigração Portuguesa: Relatório Estatístico 2014. Lisboa: Observatório da Emigração e Rede Migra.

Podsakoff, P.M., Mackenzie, S.B., Lee, J.Y. \& Podsakoff, N.P. (2003). Common method bias in behavioral research: A critical review of the literature and recommended remedies. Journal of Applied Psychology, 88(5), 879-903. 
Rienzo, C. \& Vargas-Silva, C. (2016). Migrants in the UK: an overview (5 $5^{\text {th }}$ Ed). Oxford: The Migration Observatory at the University of Oxford.

Robie, C. \& Ryan, A.M. (1996). Structural equivalence of a measure of cross-cultural adjustment. Educational and Psychological Measurement, 56(3), 514-521.

Rothwell, A. \& Arnold, J. (2007). Self-perceived employability: Development and validation of a scale. Personnel Review, 36(1), 23-41.

Selmer, J. \& Lauring, J. (2010). Self-initiated academic expatriates: inherent demographics and reasons to expatriate. European Management Review, 7(3), 169-179.

Shaffer, M.A., Harrison, D.A. \& Gilley, K.M. (1999). Dimensions, determinants, and differences in the expatriate adjustment process. Journal of International Business Studies, 30(3), 557-581.

Suutari, V. \& Brewster, C. (2000). Making their own way: International experience through self-initiated foreign assignments. Journal of World Business, 35(4), 417-436.

Takeuchi, R. (2010). A critical review of expatriate adjustment research through a multiple stakeholder view: progress, emerging trends, and prospects. Journal of Management, 36(4), 1040-1064.

Tharenou, P. \& Caulfield, N. (2010). Will I stay or will I go? Explaining repatriation by selfinitiated expatriates. Academy of Management Journal, 53(5): 1009-1028.

Tremblay, M., Cloutier, J., Simard, G., Chênevert, D. \& Vandenberghe, C. (2010). The role of HRM practices, procedural justice, organizational support and trust in organizational commitment and in-role and extra-role performance. The International Journal of Human Resource Management, 21(3), 405-433.

Van den Broeck, A., De Cuyper, N., Baillien, E., Vanbelle, E., Vanhercke, D. \& De Witte, H. (2014). Perception of organization's value support and perceived employability: 
insights from self-determination theory. The International Journal of Human Resource Management, 25(13), 1904-1918.

Vander Elst, T., De Witte, H. \& De Cuyper, N. (2014). The Job Insecurity Scale: A psychometric evaluation across five European countries. European Journal of Work and Organizational Psychology, 23(3), 364-380.

Vander Elst, T., Van den Broeck, De Cuyper \& De Witte (2014). On the reciprocal relationship between job insecurity and employee well-being: Mediation by perceived control? Journal of Occupational and Organizational Psychology, 87(4), 671-693.

Van der Heijde, C. M. \& Van der Heijden, B. I. J. M. (2006). A competence-based and multidimensional operationalization and measurement of employability. Human Resource Management, 45(3), 449-476.

Van der Heijden, B. I. J. M. (2002). Prerequisites to guarantee life-long employability. Personnel Review, 31(1), 44-61.

Ward, C. \& Kennedy, A. (1996). Crossing cultures: the relationship between psychological and socio-cultural dimensions of cross-cultural adjustment, In J. Pandey, D. Sinha and D.P.S. Bhawuk (Eds.). Asian contributions to cross cultural psychology, New Delhi: Sage Publications. 289-306.

Weston, R. \& Gore, P. A. (2006). A brief guide to structural equation modeling. The Counseling Psychologist, 34(5), 719-751.

Wittekind, A., Raeder, S. \& Grote, G. (2009). A longitudinal study of determinants of perceived employability. Journal of Organizational Behavior, 31(4), 566-586.

Wright, P.M. \& Gardner, T.M. (2003). The human resource-firm performance relationship: Methodological and theoretical challenges. In D. Holman, T. D. Wall, C. W. Clegg, P. Sparrow, \& A. Howard (Eds.). The new workplace: A guide to the human impact of modern working practices, West Sussex, UK: Wiley. 311-328. 


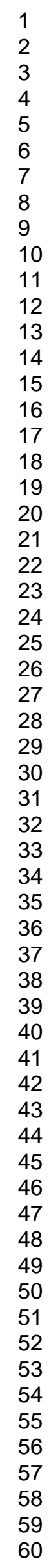

32

33

34

35

36

37

38

39

40

41

43

44

45

46

47

48

49

51

52

54

55

57

58

59

60 
Table1. Means, Standard Deviations and Correlations

\begin{tabular}{|c|c|c|c|c|c|c|c|c|c|c|c|c|c|}
\hline & Mean & S.D. & Age & Gender & Education & $\begin{array}{c}\text { Time } \\
\mathrm{HC}\end{array}$ & $\begin{array}{c}\text { Contract } \\
\text { Type }\end{array}$ & Adjustment & Training & Career & Rewards & $\begin{array}{c}\text { Internal } \\
\text { PE }\end{array}$ & $\begin{array}{c}\text { External } \\
\text { PE }\end{array}$ \\
\hline Age & 34.70 & 9.08 & 1 & & & & & & & & & & \\
\hline Gender & - & - & .03 & 1 & & & & & & & & & \\
\hline Education & 4.70 & 1.55 & $-.27 * * *$ & -.05 & 1 & & & & & & & & \\
\hline Time HC & 4.70 & 5.06 & $.48 * * *$ & .08 & $-.34 * * *$ & 1 & & & & & & & \\
\hline ContType & - & - & $.23 * * *$ & .09 & .06 & .06 & 1 & & & & & & \\
\hline Adjustment & 5.09 & 1.19 & .02 & .10 & .08 & -.02 & .11 & 1 & & & & & \\
\hline Training & 3.78 & 1.19 & -.09 & .10 & .03 & -.04 & -.02 & $.28 * * *$ & 1 & & & & \\
\hline Career & 3.76 & 1.12 & $-.13 *$ & .12 & .02 & .06 & .06 & $.28 * * *$ & $.63 * * *$ & 1 & & & \\
\hline Rewards & 3.42 & 1.15 & -.08 & $.17 *$ & .06 & .06 & .07 & $.30 * * *$ & $.49 * * *$ & $.66^{* * *}$ & 1 & & \\
\hline Internal PE & 2.82 & .10 & -.08 & -.04 & -.03 & -.04 & -.02 & .11 & $.36 * * *$ & $.51 * * *$ & $.33 * * *$ & 1 & \\
\hline External PE & 3.13 & .89 & -.06 & .10 & .00 & .03 & -.10 & -.02 & .03 & .04 & -.10 & $.29 * * *$ & 1 \\
\hline Job Insec. & 1.84 & .89 & .10 & .01 & -.03 & -.05 & -.09 & -.12 & $-.17 * *$ & $-.24 * * *$ & -.08 & .00 & $.20 * *$ \\
\hline
\end{tabular}


Table 2. Control Variables and Regression Weights

\begin{tabular}{|c|c|c|c|c|c|}
\hline \multirow[t]{2}{*}{ Dependent Variables } & \multicolumn{5}{|c|}{ Control Variables } \\
\hline & Age & Gender & Education & $\begin{array}{c}\text { Time in the Host } \\
\text { Country }\end{array}$ & Contract Type \\
\hline External Upward PE & -.07 & .09 & -.02 & .06 & -.06 \\
\hline $\begin{array}{l}\text { Adjustment to the } \\
\text { Host Country }\end{array}$ & .10 & .02 & .07 & -.08 & .04 \\
\hline
\end{tabular}

Note: $*=\mathrm{p}<.05 ; * *=\mathrm{p}<.01 ; * * * \mathrm{p}<.001$ 
$\mathrm{H}$

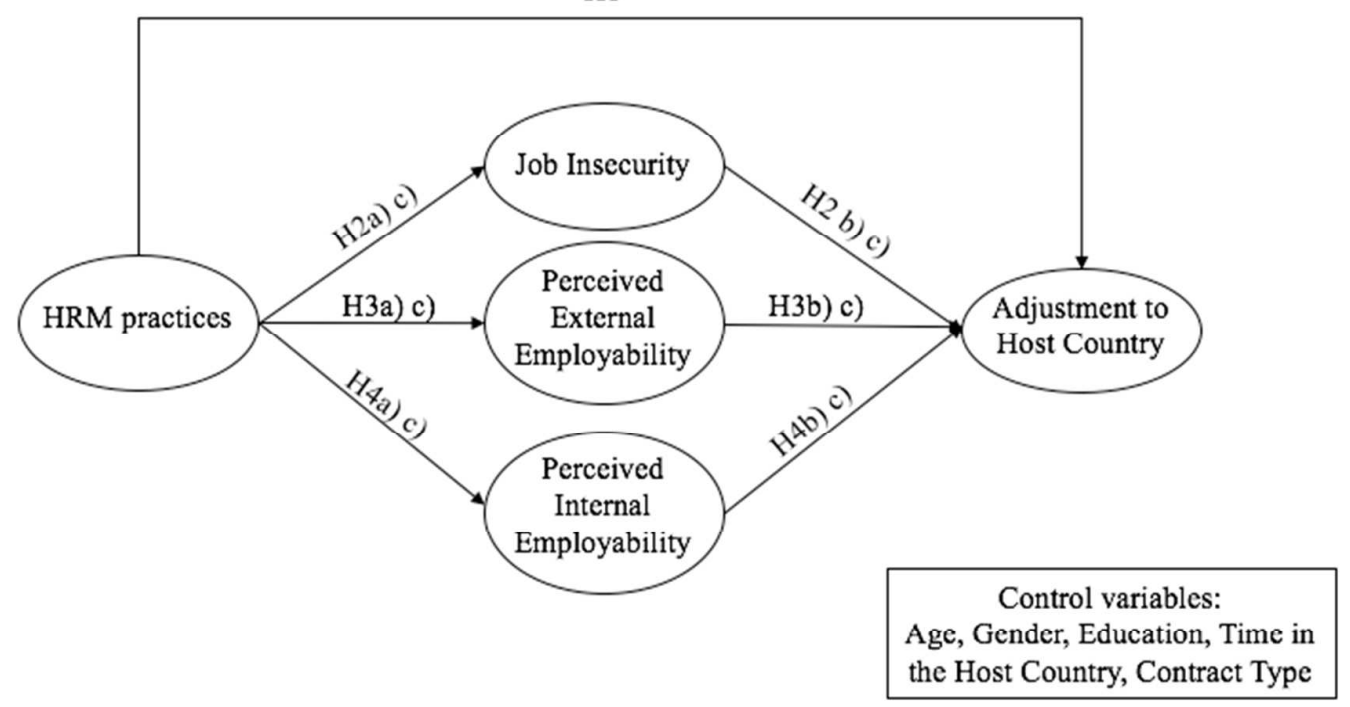

Figure 1. Hypothesised Model

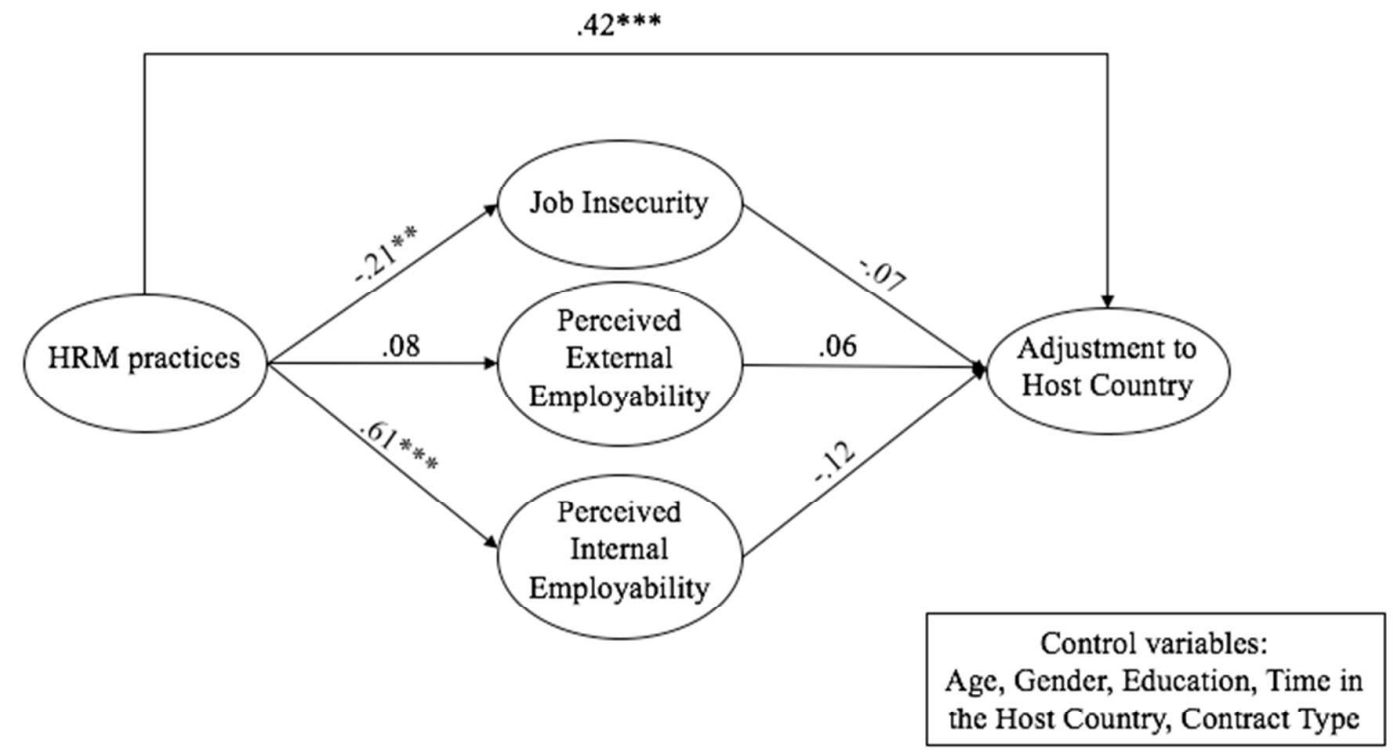

Figure 2. Results - Structural relations among HRM practices, internal and external perceived employability, job insecurity and adjustment to the host country.

Note: $*=p<.05 ; * *=p<.01 ; * * *=p<.001$ 